\title{
Effect of Dietary Mixture Containing Azolla and Spirulina Platensis on Physiological, Metabolic, Immunological and Histological Performance of GIFT- Tilapia (Oreochromis niloticus) Cultured in Lined Ponds
}

\author{
Mosha SS ${ }^{1,2 *}$, Felix $S^{2}$, Manikandavelu $\mathrm{D}^{2}$, Felix ${ }^{2}$, Samuel Moses $\mathrm{TLS}^{2}$ and Menaga $\mathrm{M}^{2}$ \\ ${ }^{1}$ Division of Training, Extension Services and Research, Ministry of Agriculture Training Institute (MATI), P.O Box 121, Mtwara, Tanzania
}

${ }^{2}$ Advanced Research Farm Facility, Department of Aquaculture, Fisheries College and Research Institute, Tamil Nadu Dr.J.J Jayalithaa Fisheries University, 601204, Mathavaram, Tamil Nadu, India

*Corresponding author: Mosha SS, Division of Training, Extension Services and Research, Ministry of Agriculture Training Institute (MATI), P.O Box 121, Mtwara, Tanzania.
Received Date: May 12, 2020

Published Date: June 01, 2020

\begin{abstract}
The study aimed to evaluate the effect of Azolla and Spirulina platensis inclution diet on physiological, immunological and histological performance of GIFT Tilapia (Oreochromis niloticus) cultured in lined ponds. With reference to pilot studies conducted in different Azolla and S. platensis inclusion levels, an isonitrogenous (32\%) and isocaloric (17 KJ kg-1 DM) diet (15\%-Azolla and 3\%- S.platensis meal) was formulated to replace fishmeal, while commercial diet was used as control. Animals $(5.5 \pm 0.04 \mathrm{~g})$ were randomly stocked at a density of $15 \mathrm{~m}^{-3} \mathrm{in} 100 \mathrm{~m}^{2}$ lined ponds in all the experimental diets in triplicates. The fishes were fed with experimental diets at $5 \%$ of their body weight in two rations throughout the 90 days trial. The results indicated that, water quality parameters ( $\mathrm{pH}$, alkalinity, hardness and nitrate), physiological parameters, immunological indices and intestinal villi structure were significantly higher in test diet, while metabolic enzyme activity and liver histology were not influenced by the dietary treatments. Therefore, the study suggests that, partial replacement of fish meal with a combination of Azolla (15\%) and S. platensis (3\%) meal in semi intensive GIFT tilapia culture is beneficial for the better performance of GIFT tilapia, $O$. niloticus production.
\end{abstract}

Keywords: Azolla; Spirulina platensis; GIFT tilapia; Digestive enzymes; Immunity; Carotenoid content

\section{Introduction}

Fish supply from aquaculture sector play a significant role in contributing to food security, poverty alleviation and economic development [1]. The sector is highly depending on the use of fish meal as amajor source of protein in feed formulation. Fish meal has been the protein source of choice in aquafeeds for many reasons, including its high protein content, excellent amino acid profile, high nutrient digestibility, general lack of antinutrients etc. However, the irregular supply and high cost form the main constraints in using this conventional ingredient for fish feeds, which greatly impacts the profitability of tilapia farming [2]. Therefore, the use of nonconventional plants based ingredients as alternatives of fish meal could reduce the costs of feed in effective manner. Aquatic plants and microalgaeare among of the nonconventional plants protein sources which can be utilized by different fish species. Its utilization as feed ingredients has taken a new dimension in producing the required animal protein at low cost [3]. Some aquatic plants which can be used in tilapia diet, among others, are Azzola piñata, Salvinia molesta, Lemna minor and Ipomoea 
aquatic [4]. In addition, several macro- and microalgae species such as Ascochloris spp, Gliricidia maculate, Colocasiae sculenta, Leucaenal eucocephala and Eichornia crassipes have also reported to be successful incorporated in fish diets [3,5-7]. Among aquatic plants and microalgae, Azolla and Sprirulina platensis are ease to be cultivated, have higher productivity and nutritive value, rich on essential amino acids, vitamins and minerals, pigments, improving digestive system and immune functions $[8,9]$. Indeed, the potential use of these nonconventional plant ingredients is needed for a rapid fish production [10]. Among tilapia strains which reported to convert raw protein from Azolla and Spirulina into the best digestible protein to maintain high metabolic rates and increased growth performance is Genetically Improved Farmed Tilapia (GIFT), an enhanced strain of Nile tilapia (Oreochromis niloticus) [11]. GIFT strain is developed to be fast growing and adaptable to a wide range of environmental conditions [12]. Its culture represents approximately $80 \%$ of cultured tilapia worldwide [13]. In India, GIFT strain has been imported in conjunction with World Fish [14]. In studies conducted at CIFA during the year 1998 to 2000, GIFT tilapia demonstrated high production of 5-6 $\mathrm{mt}$ per crop for 4-6 months duration [15]. Recently, it is produced in private and state department licensed hatcheries, and is the most popular among the Nile tilapia strains [16]. Its production reported to have a significant impact on poverty alleviation and livelihoods support
[17]. However, due to high price and low availability of fish meal, the cost of pelleted feeds has been increased, in turn compromise the profitability of tilapia farming [2]. Further, the reports on use of nonconventional plants based ingredients on the physiology of GIFT tilapia strain are limited. Hence, the present study was conducted to assess the effect of dietary mixture containing Azolla and S. platensis on physiological, immunological and histological performance of GIFT Tilapia (Oreochromis niloticus) cultured in lined ponds.

\section{Materials and Methods}

\section{Experimental diets and feeding}

Based on pilot scale studies conducted earlier, individual inclusion of Azolla at 15\% and Spirulina platensis at 3\% showed significant growth performance in GIFT tilapia culture. With reference to this, an isonitrogenous (32\%) and isocaloric (17 $\mathrm{KJ} \mathrm{kg}^{-1} \mathrm{DM}$ ) diet was formulated to replace fish meal with Azolla and S. platensis at $15 \%$ and $3 \%$ respectively (Table $1 \& 2$ ), while commercial diet (growel) was used as control. Animals weighing $(5.5 \pm 0.04 \mathrm{~g})$ were randomly stocked at a density of $15 \mathrm{~m}^{-3}$ in $100 \mathrm{~m}^{2}$ lined ponds in all the experimental diets in triplicates. The fishes were fed with experimental diets at $5 \%$ of their body weight in two rations for all the treatments throughout the 90 days feeding trial.

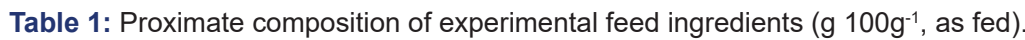

\begin{tabular}{|c|c|c|c|c|c|}
\hline \multirow{2}{*}{ Ingredients } & \multicolumn{5}{|c|}{ Proximate Composition (\%) } \\
\hline & Crude Protein & Ether Extract & Crude Fibre & Total Ash & Moisture \\
\hline Fish meal & 60.28 & 13.76 & $<1$ & 14.83 & 10.62 \\
\hline Azolla meal & 23.99 & 3.37 & 13.84 & 18.1 & 10 \\
\hline Spirulina meal & 58.37 & 2.35 & 1.99 & 7.12 & 8.8 \\
\hline Soybean meal & 47.17 & 1.52 & 5.3 & 7.46 & 5.39 \\
\hline Corn flour & 7.87 & 4.31 & 1.4 & 1.69 & 6.67 \\
\hline Cassava starch & 9 & - & - & - & - \\
\hline Groundnut Oil Cake & 39.21 & 10.11 & 5.35 & 3.77 & 17.65 \\
\hline
\end{tabular}

Table 2: Proximate composition of the experimental diets $\left(\mathrm{g} 100 \mathrm{~g}^{-1}\right.$, as fed).

\begin{tabular}{|c|c|c|}
\hline \multirow{2}{*}{ Ingredients (\%) } & \multicolumn{2}{|c|}{ Experimental Diets } \\
\cline { 2 - 3 } & Basal & 31.8 \\
\hline Crude protein & 32 & 2.5 \\
\hline Crude Fat & 1.5 & 5 \\
\hline Crude fibre & 2 & 15 \\
\hline Total ash & 12 & 4.8 \\
\hline Moisture & 6.2 & 17.07 \\
\hline Gross Energy $\left(\mathrm{Kj} \mathrm{kg}^{-1}\right)$ & 17.1 & \\
\hline
\end{tabular}

\section{Water quality parameters}

The water quality parameters were monitored throughout the experimental trial. Temperature (Pro 20, YSI-USA), Dissolved Oxygen (Pro 20, YSI-USA) and pH (model: LT-10) were monitored daily. Nitrite $\left(\mathrm{NO}_{2}-\mathrm{N}\right)$, Ammonia $\left(\mathrm{NH}_{3}-\mathrm{N}\right)$, Nitrate $\left(\mathrm{NO}_{3}-\mathrm{N}\right)$, Total hardness and Total alkalinity were measured weekly once by titration method using spectrophotometer (Systronics, Ahmedabad, India) [18]. 


\section{Growth performance and survival}

The growth parameters and survival rate were evaluated at the end of 90 days feeding trial according to Olvera-Novoaet al. [19].

\section{Proximate composition analysis of ingredients, feeds and animals}

All ingredients, experimental feeds and animals were subjected to proximate composition analysis. Crude protein, crude fat, crude fibre, total ash, moisture and gross energy were analyzed according to AOAC [20]. The results for feed ingredients and experimental feeds are shown in Table 1 and 2.

\section{Antioxidant enzymes activity}

Catalase (CAT), Superoxide dismutase (SOD) and Glutathione peroxidase (GPx) activity were assayed at the end of feeding trial. CAT activity was measured according to Takaharaet al. [21]. SOD and GPx activities were assayed according to the method of Mishra \& Fridovich [22], and Paglia \& Valentine [23] respectively.

\section{Metabolic enzyme activities:}

Metabolic enzymes activity in the blood samples were assayed at the end of 90 days feeding trial. Plasma protein was estimated by Lowry [24] method. Aspartate aminotransferase (AST) and Alanine aminotransferase (ALT) activity were assayed according to Reitman and Frankel [25].

\section{Digestive enzyme activities}

At the end of experimental trial, amylase activity was determined by the starch-hydrolysis method of Bernfeld [26]. Lipase and protease activity were assayed according to Cherry and Crandall [27] and Bernfeld [26] respectively.

\section{Blood serum biochemistry}

Blood serum biochemistry contents such as total serum protein, albumin and globulin were assayed at the end of 90 days feeding trial. The serum total protein estimation was carried out by Lowry's method [24]. Albumin and globulin contents were performed following the method of Doumaset al. [28].

\section{Blood immunological indices}

Blood immunological indices such as Respiratory burst activity (RBT) in the blood plasma were assayed using the modified method of Anderson and Siwiki [29]. Myeloperoxidase activity (MPO) was measured according to Quade and Roth [30]. Plasma lysozyme activity was determined according to Shugar [31] and glucose content was assayed by using a standard kit (Beacon Diagnostics Pvt.LTD, India).

\section{Muscle quality index}

The total carotenoid concentration (TCC) in fish muscle tissues were analyzed immediately after the completion of the experiment following the pigment extraction method as described by Olson [32].

\section{Histology}

At the end of 90 days feeding trial, liver and intestinal tissues from the dietary groups were collected and preserved in $70 \%$ formalin. The histological section analysis of liver and intestinal tissues was performed according to Yuji-Sadoet al. [33] at State Referral Laboratory for Aquatic Animal Health, Tamil Nadu, India. The villi length and muscular layer thickness measurements were measured using binocular microscope (Lawrence \& Mayo, NLCD-120E) with a micrometer rule according to the methods of Spadoniet al. [34] and Eyarefeet al. [35].

\section{Statistical analysis}

Statistical analysis for all the parameters were performed using Student's T-test at $5 \%(p<0.05)$ level to compare mean between the dietary treatments. The results obtained were presented as mean \pm SE (standard error of mean). All calculations were performed using IBM SPSS Statistics V21 (IBM Cop. Armonk, New York, USA).

\section{Results and Discussion}

\section{Physico-chemical water parameters}

The mean water temperature, dissolved oxygen, total ammonia $\left(\mathrm{NH}_{4}-\mathrm{N}^{+}\right)$and nitrite $\left(\mathrm{NO}_{2}-\mathrm{N}\right)$ were not significantly different $(\mathrm{p}<$ 0.05 ) between test diet and the control (Table 3).

Table 3: Physical chemical of water in GIFT tilapia fed with experimental diets for 90 days.

\begin{tabular}{|c|c|c|}
\hline \multirow{2}{*}{ Parameters } & \multicolumn{2}{|c|}{ Experimental Diets } \\
\cline { 2 - 3 } & Basal & $6.47 \pm 0.09^{\mathrm{a}}$ \\
\hline DO $(\mathrm{mg} / \mathrm{l})$ & $6.13 \pm 0.12^{\mathrm{a}}$ & $30.33 \pm 0.03^{\mathrm{a}}$ \\
\hline Temperature $\left({ }^{0} \mathrm{C}\right)$ & $30.21 \pm 0.05^{\mathrm{a}}$ & $7.31 \pm 0.02^{\mathrm{b}}$ \\
\hline $\mathrm{p}^{\mathrm{H}}$ & $7.09 \pm 0.01^{\mathrm{a}}$ & $36.23 \pm 0.08^{\mathrm{b}}$ \\
\hline Alkalinity $(\mathrm{mg} / \mathrm{l})$ & $35.80 \pm 0.05^{\mathrm{a}}$ & $69.90 \pm 0.95^{\mathrm{b}}$ \\
\hline Hardness $(\mathrm{mg} / \mathrm{l})_{\mathrm{NO}_{3}-\mathrm{N}(\mathrm{mg} / \mathrm{l})}$ & $69.03 \pm 0.52^{\mathrm{a}}$ & $0.29 \pm 0.03^{\mathrm{b}}$ \\
\hline $\mathrm{NH}_{3}-\mathrm{N}(\mathrm{mg} / \mathrm{l})$ & $0.15 \pm 0.01^{\mathrm{a}}$ & $0.02 \pm 0.001^{\mathrm{a}}$ \\
\hline $\mathrm{NO}_{2}-\mathrm{N}(\mathrm{mg} / \mathrm{l})$ & $0.01 \pm 0.004^{\mathrm{a}}$ & $0.002 \pm 0.000^{\mathrm{a}}$ \\
\hline
\end{tabular}

Values are expressed as means \pm standard error mean $(n=90)$. Means with different superscripts letters within each row are statistically significant $(p<0.05)$. 
These values were compatible with the optimal water quality parameters of Nile tilapia [36], and were similar to those previously reported in Nile Tilapia, Oreochromis niloticus [37] fed Azolla-based-diets in earthen ponds. In addition, the $\mathrm{pH}$, alkalinity, hardness and nitrate $\left(\mathrm{NO}_{3}-\mathrm{N}\right)$ values were significantly higher $(\mathrm{p}<0.05)$ in test diet compared to the control. This leads to phytoplankton abundances which are the primary source of energy for zooplanktons. Therefore, the quick assimilation of ammonia by the phytoplankton balanced ponds' ecosystem with ideal pH [37].

\section{Growth performances and Survival}

At the end of the trial, Final weight (FW), Average daily gain (ADG), Protein efficiency ratio (PER) and Specific growth rate (SGR) of GIFT tilapia were significantly improved in test diet compared to the control (Table 4). The improvement of growth performance in the current study might be due to high nutritional quality of Azolla and S. platensis meals as they are rich in essential fatty acids (Gamma Linoleic Acid), digestive enzymes, vitamins (vitamin A and B12), minerals and pigments [38-40]. Therefore, the present findings are in accordance with the results reported in Nile tilapia, Oreochromis niloticus $[41,42]$ when fed with plant based supplemented diet. In addition, the increased SGR with
Azolla fed animals were reported by Sheeno and Sahu [43] and they have found Azolla protein concentrate (APC) can be used to the minimum extent by $16.25 \%$ by replacing $10 \%$ fish meal in diet of Labeo ruhita fry. In the present study, FCR was significantly lower $(\mathrm{p}<0.05)$ in test diet fed group compared to the control, possibly due to the optimum inclusion of Azolla and Spirulina which didn't pose any antinational activity thereby improving the feed intake. These two specific feed ingredients are known to exhibit high nutritional value at a minimal level of supplementation (Demelash, 2018). Hence, when combined have the ability to increase the absorption and assimilation of dietary protein (Yoneet al., 1986). The present findings are in agreement with Abu-Zead [44] and Dawahet al. [45] who reported that, algae and aquatic plant supplementation significantly improved growth and lower FCR in Nile tilapia. On the other hand, no significant difference was shown in survival rate among the experimental groups. This could be due to high assimilation of nutrients in Azolla and Spirulina unitalize supplemented at low quantity and natural food in the pond [46-48]. Similarly, Ungsethaphandet al. [49], El-Sheekhet al. [50] and Souza et al. [51] found that, the tilapia supplemented with plant based diet did not show a significant difference in the survival rates.

Table 4: Growth performance and survival of GIFT tilapia fed with experimental diets for 90 days.

\begin{tabular}{|c|c|c|}
\hline \multirow[t]{2}{*}{ Parameters } & \multicolumn{2}{|c|}{ Experimental Diets } \\
\hline & Basal & Test \\
\hline Initial Weight (IW, $\mathrm{g} \mathrm{kg}^{-1}$ ) & $5.56 \pm 0.04^{\mathrm{a}}$ & $5.51 \pm 0.01^{\mathrm{a}}$ \\
\hline Final weight (FW, $\left.\mathrm{g} \mathrm{kg}^{-1}\right)$ & $50.91 \pm 0.04^{\mathrm{a}}$ & $63.54 \pm 0.29^{b}$ \\
\hline Average daily gain (ADG, g) & $0.50 \pm 0.01^{\mathrm{a}}$ & $0.64 \pm 0.03^{b}$ \\
\hline Feed conversion rate (FCR) & $1.57 \pm 0.11^{\mathrm{a}}$ & $1.40 \pm 0.01^{\mathrm{b}}$ \\
\hline Protein efficiency rate (PER) & $1.28 \pm 0.04^{\mathrm{a}}$ & $1.53 \pm 0.03^{b}$ \\
\hline Specific growth rate (SGR, \%) & $0.40 \pm 0.02^{\mathrm{a}}$ & $0.59 \pm 0.03^{b}$ \\
\hline Survival rate $(\mathrm{SR}, \%)$ & $99.51 \pm 0.04^{\mathrm{a}}$ & $99.78 \pm 0.06^{a}$ \\
\hline
\end{tabular}

Values are expressed as means \pm standard error mean $(n=50)$. Means with different superscripts letters within each row are statistically significant $(p<0.05)$.

\section{Whole body proximate composition}

The body composition of fish is primarily influenced by diet composition and can be controlled through nutrition [52]. The metabolism of carbohydrate, fats, and protein in fish muscles can be enhanced due to the presence of large amounts of natural chlorophyll, $\beta$-carotene, vitamin $E$, minerals (potassium and iron) and low fiber contents that are present in most of aquatic plants and microalgae [53]. In the present study, crude protein, crude fat and total ash were significantly higher $(\mathrm{p}<0.05)$ in test diet, however, there was low moisture content (Table 5).

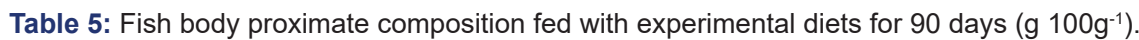

\begin{tabular}{|c|c|c|}
\hline \multirow{2}{*}{ Parameters } & \multicolumn{2}{|c|}{ Experimental Diets } \\
\cline { 2 - 3 } & Control & Treatment \\
\hline \multicolumn{1}{|c|}{ Initial whole body composition (\%) } & $31.87 \pm 0.84^{\mathrm{a}}$ \\
\hline Crude protein & $32.17 \pm 0.49^{\mathrm{a}}$ & $2.00 \pm 0.17^{\mathrm{a}}$ \\
\hline Crude fat & $2.03 \pm 0.08^{\mathrm{a}}$ & $1.93 \pm 0.07^{\mathrm{a}}$ \\
\hline Crude fiber & $1.80 \pm 0.15^{\mathrm{a}}$ & $15.04 \pm 0.05^{\mathrm{a}}$ \\
\hline Total ash & $14.90 \pm 0.10^{\mathrm{a}}$ & $1.27 \pm 0.37^{\mathrm{a}}$ \\
\hline Moisture & $1.30 \pm 0.35^{\mathrm{a}}$ & \\
\hline
\end{tabular}




\begin{tabular}{|c|c|c|}
\hline \multicolumn{2}{|c|}{ Final whole body composition (\%) } \\
\hline Crude protein & $51.17 \pm 1.53^{\mathrm{a}}$ & $59.43 \pm 1.11^{\mathrm{b}}$ \\
\hline Crude fat & $4.90 \pm 0.20^{\mathrm{a}}$ & $15.93 \pm 0.15^{\mathrm{b}}$ \\
\hline Total ash & $14.00 \pm 0.56^{\mathrm{b}}$ \\
\hline Moisture & $4.83 \pm 0.20^{\mathrm{a}}$ & $3.50 \pm 0.17^{\mathrm{b}}$ \\
\hline
\end{tabular}

Values are expressed as means \pm standard error mean $(n=50)$. Means with different superscripts letters within each row are statistically significant $(p<0.05)$.

The analysis of body muscles of the experimental fish revealed the incorporation of Azolla and Spirulina in the diet of fish increase the major nutrients composition. This might be due to the rich protein supply fern Azolla and Spirulina with a favorable amino acid profile compared to soy (Kösesakal and Yıldız, 2019). The similar improved body composition (crude protein and fat contents) were reported in African catfish, Clarias gariepinus [54], Cyprinus carpio [55] and Osphronemus gourami [56] when fed Azolla and/or Spirulina supplemented diets.

\section{Digestive enzyme activities}

In the present study, the amylase activity didn't show significant differences between dietary treatment and the control, however lipase and protease activity were significantly higher $(p<0.05)$ in test diet (Figure 1).

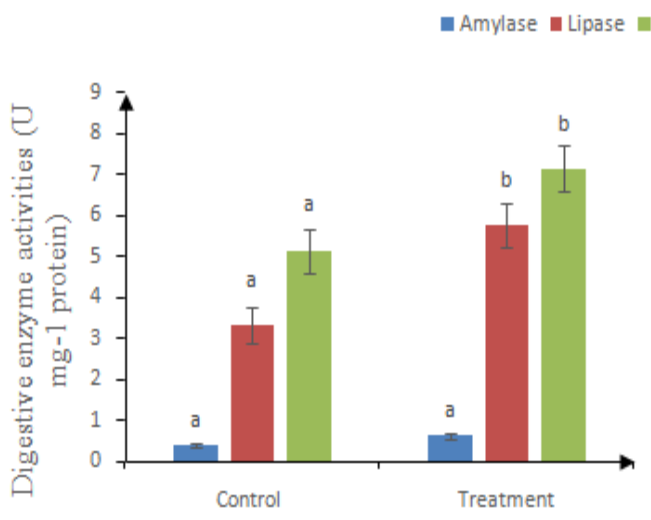

Figure 1: Digestive enzyme activities of GIFT tilapia fed with experimental diets for 90 days.

The bar with different superscript letters within the same treatment indicating the significant differences $(p<0.05),(n=50)$

The inclusion of $S$. platensis might have improved the digestion of lipoproteins that led to the increased lipase and protein activity. This paved a way for the higher growth in the test diet fed fishes. Another reason could be due to the proper formulation of the experimental diet in which protein, lipids, amino acids, vitamins and minerals composition were balanced in the diet. The nutritional requirements of GIFT tilapia were meticulously by
Azolla and Spirulina thereby deposition of major nutrients in fish muscles was clearly observed. This can also be correlated with the improved growth performance of test diet fed fishes. The findings of the present study are in agreement with the results reported in European sea bass, Dicentrarchus labrax [57] when fed microalgae supplemented diet.

\section{Antioxidant enzyme activities}

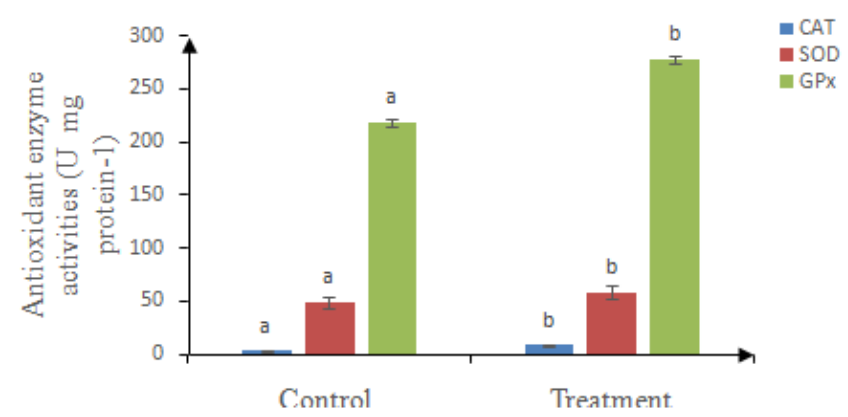

Figure 2: Antioxidant enzymatic activity of GIFT tilapia fed formulated diets for 90 days.

The bar with different superscript letters within the same treatment indicating the significant differences $(p<0.05),(n=50)(C A T-$ Catalase, SOD-Superoxide dismutase, GPx-Glutathione peroxidase activity) 
The present study revealed higher Catalase (CAT), Superoxide dismutase (SOD) and Glutathione Peroidation (GPX) activities in fish fed with test diet (Figure 2), indicating reduced cell damage, than fish fed control diet. This might be due to the presence of C-phycocyanin compound which has high anti-arthritic, antiinflammatory, neuroprotective and hepatoprotective effects, which are closely connected with its antioxidative activity and maintaining the immune capacity of the fish [52]. The similar results have been reported in tilapia when fed with aquatic plants supplemented diets (Figure 2).

\section{Metabolic enzyme activities}

Aspartate aminotransferase (AST) and Alanine aminotransferase (ALT) activity were reduced in test diet fed animals compared to the basal diet fed animals, however they were not significant (Figure 3).

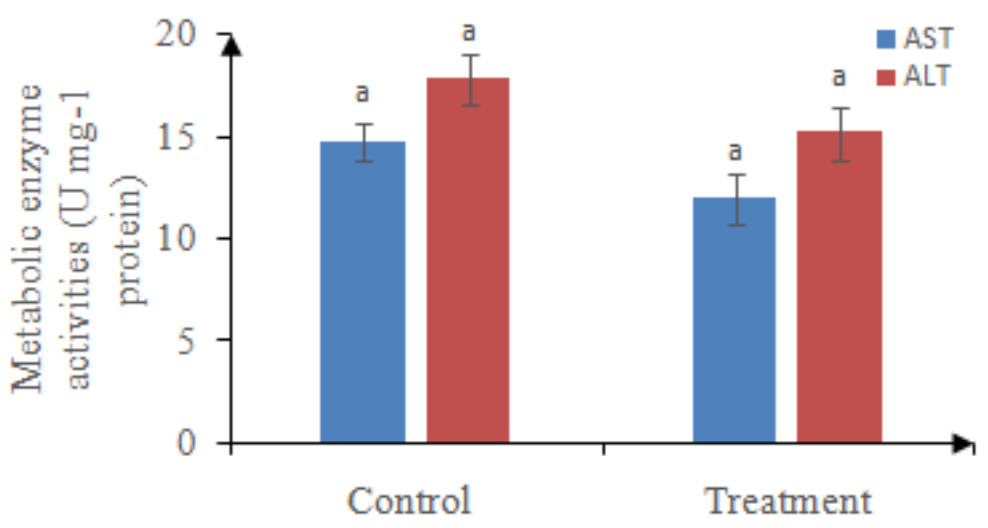

Figure 3: Metabolic enzymatic activity of GIFT tilapia fed with experimental diets for 90 days.

The bar with different superscript letters within the same treatment indicating the significant differences $(p<0.05),(n=50)($ AST- Aspartate aminotransferase, ALT- Alanine aminotransferase activity)

The results revealed that, AST and ALT activity were less in fish fed with test diet compared to the control, hence the damage of the internal organs such as liver will be lesser in test diet compared to the control [58]. The presence of some probiotics and biopolymers, and vitamins such as vitamin A, C, B12 as well as beta-carotene and minerals (iron) in Azolla and Spirulina reported to prevent fish tissues from oxidative damage and protect phagocytic cells [59]. Further, Misurcovaet al. [60] reported that, minerals which are present in aquatic plants play important functions in fish such as cell transportation and metabolic processes which serving as catalytic enzymes cofactors. The findings of the present study are in accordance with the results reported in Nile tilapia [61,62].

\section{Blood serum biochemistry}

The measurement of albumin, globulin and total protein in serum or plasma provides an indication of the enhanced immune system in fish $[63,64]$. The enhanced blood serum protein, globulin contents and $A / G$ ratio in the current study (Table 6) are in line with the increased lysozyme and myeloperoxidase (MPO) activities, suggesting immunomodulatory effects of Azolla and Spirulina on GIFT tilapia. Thus, supplementary dietary can positively affect the biochemical parameters, nutritional status and welfare of cultured tilapia. Similar findings have been reported in Nile Tilapia, Oreochromis niloticus [42], great sturgeon, Huso huso Linnaeus [65] and Gouramy, Osphronemus gouramy [56] when fed with aquatic plants and/or algae supplemented diets (Table 6).

\section{Blood immunological indices}

There was no significant difference shown in respiratory burst activity (RBT) among dietary treatments, however the highly significant difference $(\mathrm{p}<0.05)$ were observed in lysozyme and myeloperoxidase (MPO) activity in test diet fed animals (Table 7).

Table 6: Blood serum biochemistry contents of GIFT tilapia fed with experimental diets for 90 days.

\begin{tabular}{|c|c|c|}
\hline \multicolumn{2}{|c|}{ Parameters } & \multicolumn{2}{|c|}{ Experimental Diets } \\
\cline { 2 - 3 } & Control & Test \\
\hline Serum protein $\left(\mathrm{g} \mathrm{dL}^{-1}\right)$ & $69.80 \pm 2.05^{\mathrm{a}}$ & $77.60 \pm 3.18^{\mathrm{b}}$ \\
\hline Albumin $\left(\mathrm{g} \mathrm{dL}^{-1}\right)$ & $4.51 \pm 0.28^{\mathrm{a}}$ & $4.59 \pm 0.40^{\mathrm{a}}$ \\
\hline Globulin $\left(\mathrm{g} \mathrm{dL}^{-1}\right)$ & $65.29 \pm 3.08^{\mathrm{a}}$ & $72.97 \pm 5.31^{\mathrm{b}}$ \\
\hline A/G ratio & $0.14 \pm 0.01^{\mathrm{a}}$ & $0.22 \pm 0.02^{\mathrm{b}}$ \\
\hline
\end{tabular}

Values are expressed as means \pm standard error mean $(n=50)$. Means with different superscripts letters within each row are statistically significant $(p<0.05)$. 
Table 7: Immunological indices of GIFT tilapia fed with experimental diets for 90 days.

\begin{tabular}{|c|c|c|}
\hline \multirow{2}{*}{ Parameters } & \multicolumn{2}{|c|}{ Experimental Diets } \\
\cline { 2 - 3 } & Control & $0.25 \pm 0.04^{\mathrm{a}}$ \\
\hline RBT $\left(\mathrm{U} \mathrm{mL}^{-1}\right.$ enzyme) & $0.23 \pm 0.02^{\mathrm{a}}$ & $321.60 \pm 3.35^{\mathrm{b}}$ \\
\hline Lysozyme $\left(\mathrm{U} \mathrm{mL}^{-1}\right.$ enzyme $)$ & $314.30 \pm 7.56^{\mathrm{a}}$ & $11.28 \pm 1.00^{\mathrm{b}}$ \\
\hline MPO $\left(\mathrm{U} \mathrm{mg}^{-1}\right.$ protein) & $6.84 \pm 0.70^{\mathrm{a}}$ & $106.20 \pm 7.17^{\mathrm{b}}$ \\
\hline Glucose $\left(\mathrm{U} \mathrm{mg}^{-1}\right.$ protein $)$ & $148.95 \pm 4.35^{\mathrm{a}}$ & \\
\hline
\end{tabular}

The improved immune stimulating capacity (RBT and MPO) in fish might be due to the presence of antimicrobial compounds such as C-phycocyanin which reported to boost the immunity capacity and fight off any infections arise [4]. Promya and Chitmanat [66] and Liu etal. [67] reported that, Azolla and S.platensis contain phycocyanin and polyunsaturated fatty acids (PUFAs) particularly docohesaexanoic acid (DHA) which enhanced immune-stimulatory (white blood cells) in fish. The findings of the present study are in accordance with the results reported in Nile Tilapia [68], when administered with $S$. platensis supplemented diets. The lysozyme activity is one of the defensive factors against invasion by microorganisms [69]. The higher values reported in the present study revealed the improvement of the immune system in fish. Our results are in agreement with the findings of Nile Tilapia, Oreochromis niloticus [70] and Great sturgeon, Huso huso [65] when fed plant based diets. On the other hand, the glucose content in the present study was significantly lower $(\mathrm{p}<0.05)$ in the test diet compared to the control (Table 7), possibly due to the reduction of erythrocytosis and gluconeogenesis activity in fish which are related to the physiological stress [71]. Therefore, the low levels of glucose content recorded in the present study revealed the tolerant capacity of fish against physiological stress. Similar result has been reported in Common Carp, Cyprinus carpio when fed plant based diet (Phoneix dactylifera) at 15\% inclusion level.

\section{Muscle quality index}

Consumer acceptability of fish products rely on pigmentation such as carotenoid concentration in muscles. In the present study, total carotenoid concentration (TCC) in fish muscles was significantly higher $(\mathrm{p}<0.05)$ in test diet compared to the control (Figure 4).

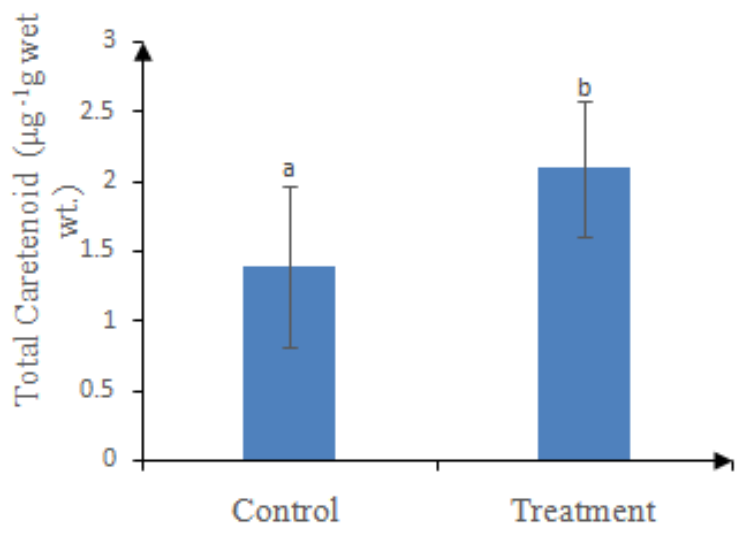

Figure 4: Total carotenoid concentration (TCC) of GIFT tilapia fed with experimental diets for 90 days.

The bar with different superscript letters within the same treatment indicating the significant differences $(p<0.05),(n=50)$

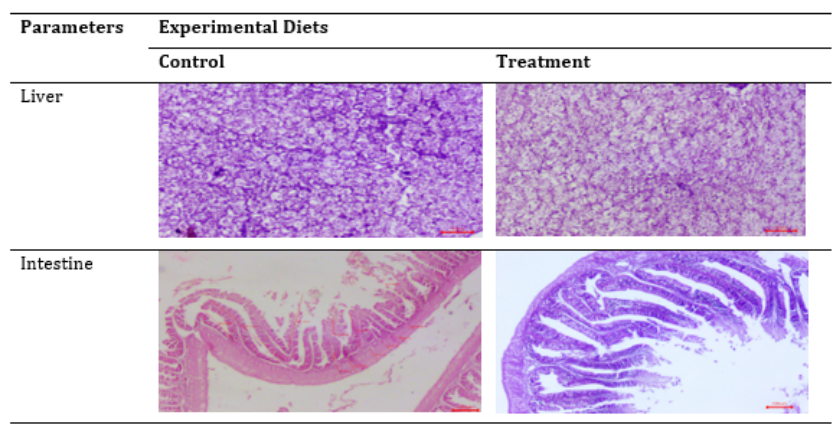

Figure 5: Liver and Intestine histological changes of GIFT tilapia fed formulated diets for 90 days.

Each image was read under microscope at 50 micro meter. 
The bioactive compound (astaxanthin) found in Azolla and Spirulina which are important in the formation of polyunsaturated fatty acid in fish muscles could explain the high values reported in the present study [72]. Also, the carotenoid content improves transportation of lipoproteins which enhance fish muscles and growth [73]. The results are in agreement with the findings of BinDohaishet al. [70] in Nile tilapia (Oreochromis niloticus) when fed with aquatic plant based diets. Therefore, the supplementation of
Azolla and Spirulina at minimal amount improves the overall fish quality, flesh firmness and taste [74,42].

\section{Histology}

The effects of plant based feeds in fish gut morphology are species-specific and the dietary inclusion levels [75]. In the present study, there were no morphological changes observed in fish liver among the experimental groups (Figure 5).

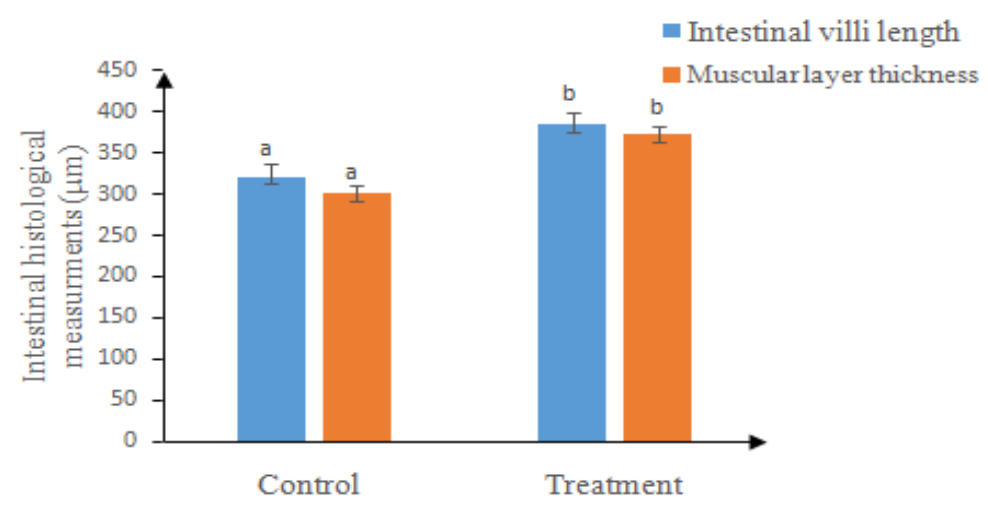

Figure 6: Intestinal histological changes on GIFT tilapia fed with experimental diets for 90 days.

The Bar with different superscript letters within the same treatment indicating the significant differences $(p<0.05)$, $(n=5)$.

Hence, the histological analysis of the present study suggests that no liver damage was attributed due to the supplementation of plant based ingredients. The findings are in accordance with results reported in Nile tilapia, 0 . niloticus $[76,51]$ and Senegalese sole, Solea senegalensis [77], when fed diets contained macro and microalgae. In addition, there were significant increase of intestinal villi length and muscular layer thickness in supplemented diet than the control (Figure 6).

This might be due to the availability of biochemical compounds in aquatic plants or algae when incorporated in fish diets [77]. The present findings are in agreement with the results reported in Nile Tilapia, Oreochromis niloticus [42]. Therefore, the present study reveal that, Azolla and Spirulina are a good source of fish feed at limited inclusion levels to optimize its digestion due to less fiber and cellulose contents [78-89]. The nutrient absorption was also improved due to increased villi length which could be advantageous in pond culture.

\section{Conclusion}

The use of nonconventional plant based ingredients and their combined effect in aqua feeds promotes intestinal health and improves fish performance. The findings of the present study for the first time revealed that, the effective incorporation of Azolla(15\%) and S. platensis (3\%) in GIFT tilapia diet can improve growth of fishes and enhance body composition, digestive, antioxidant and metabolic enzymes activities, blood serum and immunological indices, thereby reducing the cost of feed. However, more research efforts are needed on the complete replacement of fish meal to improve the digestibility and identification of unknown anti-nutritional factors of the plants origin ingredients to enhance growth performance and feed utilization in fish. Also, these findings merit further exploration in disease challenge studies.

\section{Acknowledgement}

The authors are very grateful to the Government of India through Indian Council of Agricultural Research (ICAR) and African Union (AU) for providing the financial support in the form of Research Fellowship for the period of doctoral study of the first author.

\section{Conflict of Interest}

No conflict of Interest.

\section{References}

1. FAO (2017) Aquaculture governance and sector development. FAO technical guidelines for responsible fisheries. No.5. Suppl.7. Rome, Italy. pp.50

2. Magouz FI, Dawood MAO, Salem MFI, Mohamed AAI (2020) The effects of fish feed supplemented with Azolla meal on the growth performance, digestive enzyme activity, and health condition of genetically-improved farmed tilapia (Oreochromis niloticus). Annals of Animal Science.

3. Gangadhar B, Umalatha H, Hegde G, Sridhar N (2017) Digestibility of Dry Matter and Nutrients from Azolla pinnata by Labeo calbasu (Hamilton, 1822) with a Note on Digestive Enzyme Activity. Fishery Technology 54: 94-99.

4. Nekoubin H, Sudagar M (2013) Effect of different types of plants (Lemna Sp., Azolla filiculoides) and artificial diet (with two protein levels) on growth performance, survival rate, biochemical parameters and body composition of grass carp (Ctenopharyngodon idella). Journal of Aquaculture Research and Development 4:2. 
5. Youssouf A (2012) Water quality and sediment features in ponds with Nile tilapia (Oreochromis niloticusL.) fed Azolla. Journal of Fisheries and Aquaculture 3: 47-51.

6. Mosha SS (2018) A Review on Significance of Azolla Meal as a Protein Plant Source in Finfish Culture. Journal of Aquaculture Research and Development 9: 7.

7. Sharma SV, Shah E, Davla D, Dixit G, Patel A, et al. (2019) Effect of microalga-based diet on oxidative stress enzymes of African catfish, Clarias gariepinus. International Aquatic Research 11: 377-387.

8. Volkmann H, Imianovsky U, Oliveira JLB, Sant-Anna ES (2008) Cultivation of Arthrospira platensis in desalinator wastewater and salinated synthetic medium: protein content and amino acid profile. Brazilian Journal of Microbiology 39: 98-101.

9. Panigrahi S, Choudhary D, Sahoo JK, Das SS, Rath RK (2014) Effect of dietary supplementation of Azolla on growth and survibility of Labeo rohita fingerlings. Asian J Animal Sci 9: 33-37.

10. Kumari R, Ojha ML, Saini VP, Sharma SK (2017) Effect of Azolla supplementation on growth of rohu Labeo rohita fingerlings. Journal of Entomology and Zoology Studies 5: 1116-1119.

11. Dawood MAO, Koshio S (2019) Application of fermentation strategy in aquafeed for sustainable aquaculture. Reviews in Aquaculture.

12. Dawood MAO, Magouz FI, Salem MFI, Abdel-Daim HA (2019b) Modulation of digestive enzyme activity, blood health, oxidative responses and growth-related gene expression in GIFT by heat-killed Lactobasilus plantarum (L-137). Aquaculture 505: 127-136.

13. FAO (2018) The FAO Blue Growth Initiative, in: Menezes A, Bartley D, Metzner R, Ansah Y (Eds.), Strategy for the Development of Fisheries and Aquaculture. FAO Fisheries and Aquaculture Circular No. 1161, Rome, Rome, Italy. pp. 6-10.

14. Singh A, Lakra W (2011) Risk and benefit assessment of alien fish species of the aquaculture and aquarium trade into India. Reviews in Aquaculture 3: 3-18.

15. NFDB (National Fisheries Development Board) (2015) Guidelines for responsible farming of tilapia in India. Dept. of Animal Husbandry, Dairying and Fisheries, Ministry of Agriculture and Farmers welfare, Govt. of India, KrishiBhavan, New Delhi.

16. Menaga M, Fitzsimmons K (2017) Growth of the Tilapia Industry in India. World Aquaculture pp. 49-52

17. Yuvarajan P, Felix S, Antony C, Gopalakannan A, Menaga M, Ezhilmathi S (2018) Nursery intensive rearing of GIFT tilapia inoutdoor lined pond utilizing aerobic microbialfloc technology (AMFT). Journal of Entomology and Zoology Studies 6(3): 705-709

18. APHA (2005) Standard methods for the examination of water and waste water, 21st ed. American Public Health Association, Washington, DC.

19. Olvera-Novoa MA, Campos G, Sabido GM, Martinez-Palacios CA (1990) The use of alfalfa leaf protein concentrates as a protein source in diets for tilapia (Oreochromis mossambicus). Aquaculture 90: 291-302.

20. AOAC, (Association of Official Analytical Chemist) (2005) In: Official Methods of Analysis of AOAC International. Cunniff PA (ed.), Association of Official Analytical Chemist Press, Washington DC. pp. 67-98

21. Takahara S, Hamilton HB, Neel JV, Kobara TY, Ogura Y, Nishimuiu ET (1960) Hypocatalasemia: a new genetic carrier state. Journal of Clinical Investigation 39(4): 610-619.

22. Mishra HP, Fridovich I (1972) The Role of Superoxide Anion in the Autoxidation of Epinephrine and a Simple Assay for Superoxide Dismutase. Journal of Biological Chemistry 247: 3170-3175.

23. Paglia DE, Valentine WN (1967) Studies on quantitative and qualitative characterization of erythrocyte glutathione peroxidase. Journal of Laboratory and Clinical Medicine 70(1): 158-169.

24. Lowry OH, Rosebrough NJ, Farr AL, Randall RJ (1951) Protein measurement with the folin-phenol reagents. Journal of Biological Chemistry 193(1): 265-275.
25. Reitman S, Frankel S (1957) A Colorimetric Method for the Determination of Serum Glutamic Oxalacetic and Glutamic Pyruvic Transaminases. American Journal of Clinical Pathology 28(1): 56-63.

26. Bernfeld P (1955) Methods in Enzymology. (Colowick SP, Kaplan NO eds), Academic Press, New York pp. 1-149.

27. Cherry IS, Crandall LA (1932) The specificity of pancreatic lipase: Its appearance in the blood after pancreatic injury. American Journal of Physiology 100: 266-273.

28. Doumas BT, Watson WA, Biggs HG (1971) Albumin standards and the measurement of serum albumin with bromcresol green Clinicachimicaacta 31(1): 87-96.

29. Anderson DP, Siwicki AK (1995) Basic hematology and serology for fish health programs, In: Shariff M, Arthur JR, Subasinghe JP (Eds), Fish Health Section. Asian Fisheries Society, Manila, Philippine, pp. 185-202.

30. Quade MJ, Roth JA (1997) A rapid, direct assay to measure degranulation of bovine neutrophil primary granules. Veterinary Immunology and Immunopathology 58(3-4):239-248.

31. Shugar D (1952) The measurement of lysozyme activity and the ultraviolet inactivation of lysozyme. Biochimica et BiophysicaActa 8(3): 302 309.

32. Olson A (1979) A simple dual assay for vitamin A and carotenoids in human and liver. Nutrition report international 19: 807-813

33. Yuji-Sado R, Raulino-Domanski F, Franchi de Freitas P, Baioco-Sales F (2015) Growth, immune status and intestinal morphology of Nile tilapia fed dietary prebiotics (mannan oligosaccharides-MOS). Latin American Journal of Aquatic Research 43(5): 944-952.

34. Spadoni JM, Aguilar-Nasciment, JE, Silva MH, Spadoni-Neto B, Costa PA (2005) Effects of combined use of glutamine and growth hormone in the intestinal after massive resection of the small bowel in rats. Acta Cirurgica Brasileira 20(5): 382-389.

35. Eyarefe OD, Emikpe BO, Arowolo FO (2008) Small bowel responses to enteral honey and glutamine administration following massive small bowel resection in rabbit. African Journal of Medicine and Medical Sciences 37(4): 309-314.

36. Buck EL, Mizubuti IY, Alfieri AA, Otonel RAA, Buck LY, et al. (2017) Effect of propolis ethanol extract on myostatin gene expression and muscle morphometry of Nile tilapia in net cages. Genetics and Molecular Research 16(1): 1-13

37. Abou Y, Fiogbe ED, Micha JC (2007) A preliminary assessment of growth and production of Nile tilapia, Oreochromis niloticusL., fed Azolla-baseddiets in earthen ponds. Journal of Applied Aquaculture 19(4): 55-69.

38. Kim SS, Rahimnejad S, Kim KW (2013) Partial replacement of fish meal with Spirulina Pacifia in diets for parrot fish (Oplegnathus fasciatus). Turkish Journal of Fisheries and Aquatic Science 13: 197-204.

39. Saranraj P, Sivasakthi S (2014) Spirulina platensis - Food for future: A Review. Asian Journal ofPharmaceutical Science and Technology 4(1): 26-33.

40. Kokou F, Sarropoulou E, Kentouri M (2015) Effects of fishmeal replacement by a soybean protein on growth, histology, selected immune and oxidative status markers of gilthead sea bream, Sparus aurata. Journal of the World Aquaculture Society 46: 115- 128

41. Abu-Elala NM, Galal MK, Abd-Elsalam RM, Mohey Elsaeed O, Ragaa NM (2016) Effects of dietary supplementation of Spirulina platensis and Garlic on the growth performance and expression levels of immune-related genes in Nile tilapia (Oreochromis niloticus). Journal of Aquaculture Research and Development 7(7): 433-442.

42. Khalila HS, Fayed WM, Mansour AT, Srour TM, Omar EA, et al. (2018) Dietary Supplementation of Spirulina, Arthrospira platensis, With Plant Protein Sources and their Effects on Growth, Feed Utilization and Histological Changes in Nile Tilapia, Oreochromis niloticus. Journal of Aquaculture Research and Development 9:10.

43. Sheeno TP, Sahu NP (2006) Use of freshwater aquatic plants as a substitute of fishmeal in the diet of labeorohita fry. Journal ofFisheries and Aquatic Science 1: 126-135. 
44. Abu-Zead MY (2001) Studies on some plants used for fish nutrition. Ph.D. Thesis Faculty of Agriculture, AL-Azhar University, Egypt.

45. Dawah MA, Khater AM, Shaker IMA, Ibrahim NA (2002) Production of Scenedesmus Bijuga (Chlorophyceae) in large scale in outdoor tanks and its use in feeding monosex Nile tilapia (Oeochromis niloicus) fry. Journal of Egyptian Academic Society for Environmental Development 2: 113125.

46. Fiogbe ED, Micha JC, Van Hove C (2004) Use of a natural aquatic fern Azolla microphylla, as a main component in food for the omnivorous phytoplanktonophagous tilapia, Oreochromis niloticus L. Journal of Applied Ichthyology 20: 517-520.

47. Fasakin EA, Balogun AM, Fagbenro OA (2008) Evaluation of Sun-Dried Water Fern, Azolla africana and Duckweed, Spirodela polyrrhiza in Practical Diets for Nile Tilapia, Oreochromis niloticus Fingerlings. Journal of Applied Aquaculture 11(4): 83-92.

48. Oliveira M, Freitas A, Carvalho A, Sena M (2009) Nutritive and nonnutritive attributes of washed-up seaweeds from the coast of Ceará Brazilian Food Chemistry 115: 254-259.

49. Ungsethaphand T, Peerapornpisal Y, Whangchai N, Sardsud U (2010) Effect of feeding Spirulina platensis on growth and carcass composition of hybrid red tilapia (Orechromis mossambicus x Oreochromis niloticus). Maejo International Journal of Science andTechnology 4(2): 331 -336.

50. El-Sheekh M, El-Shourbagy I, Salaby S, Hosny S (2014) Effect of feeding Arthrospira platensis (Spirulina) on growth and carcass composition of Hybrid Red Tilapia (Oreochromis mossambicus x Oreochromis niloticus). Turkish Journal ofFisheries and Aquatic Sciences 14: 471-478.

51. Souza FPd, Lima ECSd, Urrea-Rojas AM, Suphoronski SA, Facimoto CT, et al. (2020) Effects of dietary supplementation with a microalga (Schizochytrium sp.) on the hemato-immunological, and intestinal histological parameters and gut microbiota of Nile tilapia in net cages. PLoS ONE 15(1): e0226977.

52. Cabanero PC, Tumbokon BL, Junior AE (2016) Nutritional evaluation of Rhizoclonium riparium var implexum meal to replace soybean in the diet of the Nile tilapia fry. Israel Journal of Aquaculture-Bamidgeh 68: 1-9.

53. Islam Z (2016) Effect of Spirulina meal as feed additive on growth performance and body composition of climbing perch. M.Sc. Thesis. Department of Fisheries, University of Dhaka.

54. Abdel-Warith A, El-Sayed M, Al-Asgah N (2016) Potential use of green macroalgae Ulva lactucaas a feed supplement in diets on growth performance, feed utilization and body composition of the African catfish, Clarias gariepinus. Saudi Journal of Biological Sciences 23(3): 404-409.

55. Abdulrahman NM, Ameen HJH (2014) Replacement of fishmeal with microalgae Spirulina on common carp weight gain, meat and sensitive composition and survival. Pakistan Journal of Nutrition 13: 93-98.

56. Simanjuntak SBI, Indarmawan, Wibowo ES (2018) Impact of Fed Containing Different Levels of Diets Supplementation Spirulina platensis on Growth, Haematological, Body Composition and Biochemical Parameters, of Gurami (Osphronemus gouramy). Turkish Journal of Fisheries and Aquatic Sciences 18: 681-690.

57. Castro C, Couto A, Pérez-Jiménez A, Serra CR, Díaz-Rosales P, et al. (2016) Effects of fish oil replacement by vegetable oil blend on digestive enzymes and tissue histomorphology of European sea bass (Dicentrarchus labrax) juveniles. Fish Physiology and Biochemistry 42 (1): 203-217.

58. Sheikhzadeh N, Tayefi-Nasrabadi H, Oushani AK, Enferadi MHN (2012) Effects of Haematococcuspluvialis supplementation on antioxidant system and metabolism in rainbow trout (Oncorhynchus mykiss). Fish Physiology and Biochemistry 38(2): 413-419.

59. Anitha KC, Rajeshwari YB, Prasanna SB, Shree JS (2016) Nutritive evaluation of Azolla as livestock feed. Journal of Experimental Biology and Agricultural Sciences 4(6): 670-674.

60. Misurcova L, Machu L, Orsavova J (2011) Seaweed minerals as nutraceuticals. Advances in Food and Nutrition Research 64: 371 -390.

61. Cheng CH, Ye CX, Guo ZX, Wang AL (2017) Immune and physiological responses of pufferfish (Takifugu obscurus) under cold stress. Fish and Shellfish Immunology 64: 137-145.
62. Zou Q, Huang Y, Cao J, Zhao H, Wang G, et al. (2017) Effects of four feeding stimulants in high plant-based dietson feed intake, growth performance, serum biochemical parameters, digestive enzyme activities and appetite-related genes expression of juvenile GIFT tilapia (Oreochromis sp.). Aquaculture Nutrition 23(5):1076-1085.

63. Dossou S, Koshio S, Ishikawa M, Yokoyama S, Dawood MAO, et al. (2018a) Effect of partial replacement of fish meal by fermented rapeseed meal on growth, immune response and oxidative condition of red sea bream juvenile, Pagrus major. Aquaculture 490: 228-235.

64. Dossou S, Koshio S, Ishikawa M, Yokoyama S, Dawood MAO, et al. (2018b) Growth performance, blood health, antioxidant status and immune response in red sea bream (Pagrus major) fed Aspergillus oryzae fermented rapeseed meal (RMKoji). Fish and Shellfish Immunology 75: 253-262.

65. Yeganeh S, Adel M (2018) Effects of dietary algae (Sargassum ilicifolium) as immunomodulator and growth promoter of juvenile great sturgeon (Huso huso Linnaeus, 1758). Journal of Applied Phycology 3(1): 4-13.

66. Promya J, Chitmanat C (2011) The effects of Spirulina platensis and Cladophora algae on the growth performance meat quality and immunity stimulating capacity of the African sharptooth catfish (Clarias gariepinus). International Journal of Agriculture and Biology 13(1): 77-82.

67. Liu Q Huang Y, Zhang R, Cai T, Cai Y (2016) Medical Application of Spirulina platensis Derived C-Phycocyanin. Hindawi Publishing Corporation Evidence-Based Complementary and Alternative Medicine p.14

68. Zeinab AK, Aly MS, Faiza AK, Fatma EM (2015) Effect of Spirulina platensis and Lactobacillus rhamnosa on growth and biochemical performance of Nile Tilapia (Orechromis niloticus) fingerlings. International Journal of Current Microbiology andApplied Sciences 4(4): 747-763.

69. Ibrahem MD, Mohamed MF, Ibrahim MA (2013) The role of Spirulina platensis (Arthrospira platensis) in growth and immunity of Nile tilapia (Oreochromis niloticus) and its resistance to bacterial infection. Journal of Agricultural Science 5(6): 109-117.

70. Bin-Dohaish E, Al Dhahri M, OMAR H (2018) Potential application of the blue-green alga (Spirulina platensis) as a supplement in the diet of Nile tilapia (Oreochromis niloticus). Applied ecology and environmental research 16(6): 7883-7902.

71. Telli GS, Ranzani-Paiva MJT, Dias DC, Sussel FR, Ishikawa CM, Tachibana L (2014) Dietary administration of Bacillus subtilis on hematology and non-specific immunity of Nile tilapia Oreochromis niloticus raised at different stocking densities. Fish and Shellfish Immunology 39(2):305311.

72. Soler-Vila A, Coughlan S, Michael D, Guiry M, Kraan S (2009) The red alga Porphyra dioica as a fish-feed ingredient for rainbow trout (Oncorhynchus mykiss): effect on growth, feed efficiency and carcass composition. Journal of Applied Phycology 21: 617-624.

73. Wongputtisin P, Sompong U (2015) Biomass production of Spirulina platensis in medium containing effluent from Para rubber sheet manufacturing process. Biology education and research in a changing planet. Esther GnanamalarSarojini Daniel (Eds.), Springer, Singapore pp. 197-205.

74. Guroy D, Sahin I, Guroy B, Altin A, Merrifield D (2012) Effect of dietary protein level on growth performance and nitrogen excretion of yellow tail cichlid Pseudotropheus acei. The Israeli Journal of Aquaculture 64: $1-6$

75. Vizcaín AJ, Mendes SI, Varela JL, Ruiz-Jarabo I, Rico R, et al. (2015) Growth, tissue metabolites and digestive functionality in Sparus aurata juveniles fed different levels of macroalgae, Gracilaria cornea and Ulva rigida. Aquaculture Research 4:3224-3238.

76. Silva DM, Valente LMP, Sousa-Pinto I, Pereira R, Pires MA, et al. (2015) Evaluation of IMTA-produced seaweeds (Gracilaria, Porphyra, and Ulva) as dietary ingredients in Nile tilapia, Oreochromis niloticusL, juveniles Effects on growth performance and gut histology. Journal of Applied Phycology 27: 1671-1680. 
77. Vizcaíno AJ, Fumanal M, Sáez MI, Martínez TF, Moriñigo MA, et al. (2019) Evaluation of Ulva ohnoi as functional dietary ingredient in juvenile Senegalese sole (Solea senegalensis): Effects on the structure and functionality of the intestinal mucosa. Alga Research 42:101608.

78. Holman B, Malau-aduli A (2012) Spirulina as a livestock supplement and animal feed. Journal of Animal Physiology and Animal Nutrition 97: 615623.

79. Paloma Bermejo, Enrique Pinero, Angle M Villar (2008) Iron-chelating ability and antioxidant properties of phycocyanin isolated from a protean extract of Spirulina platensis. Food Chem 110(2): 436-445.

80. Bindu M, Sobha V (2005) Impact of marine algal diets on the feed utilization and nutrient digestibility of grass carp Ctenopharyn godonidella. Ecology and Noospherology 16: 1-2.

81. Choubert G, De La Noue J, Blanc J (1991) Apparent digestibility of canthaxanthin in rainbow trout: effect of dietary fat level, antibiotics and number of Pyloric caeca. Aquaculture 99: 323-329.

82. Eichmiller JJ, Hamilton MJ, Staley C, Sadowsky JM, Sorensen PW (2016) Environment shapes the fecal microbiome of invasive carp species. Microbiome 44(4): 1-13.

83. Ji H, Om A, Yoshimatsu T, Hayashi M, Umino T, et al. (2003) Effect of dietary vitamins $\mathrm{C}$ and $\mathrm{E}$ fortification on lipid metabolism in red sea bream Pagrus major and black sea bream Acanthopagrus schlegeli. Fisheries Science 69: 1001 -1009.
84. Karakatsouli N (2012) An overview of the use of fatty acids in the fish farming research during the last decade, with particular emphasis on fish quality. Journal of World Aquaculture Society 43: 291 -320.

85. Mosha SS (2019) The Significance of Spirulina Meal on Fishmeal Replacement in Aquaculture. A Review.Sumerianz Journal of Agriculture and Veterinary 1: 1-9.

86. Nakono T, Yamaguchi T, Sato M, Iwama G (2003) Biological Effects of Carotenoids in Fish. In: International Seminar Effective Utilization of Marine Food Resource,Songkhla, Thailand. pp. 1-15.

87. Rodrigues VJ, Onime L, Huws SA, Odaneth AA, Lali AM (2017) Diversity of ulvan and cellulose depolymerizing bacteria associated with the green microalgae Ulva spp. Journal of Applied Biotechnology and Bioengineering 2(4): 136-142.

88. Sheeno TP, Sahu NP (2006) Use of freshwater aquatic plants as a substitute of fishmeal in the diet of Labeo rohita fry. Journal ofFisheries and Aquatic Science 1: 126-135.

89. Yone Y, Furuichi M, Urano K (1986) Effects of wakame Undaria pinnatifida and Ascophyllum nodosum absorption of dietary nutrients, and blood sugar and plasma free amino-N levels of red sea bream. Bulletin of the Japanese Society of Scientific Fisheries 52(10): 1817-1819. 